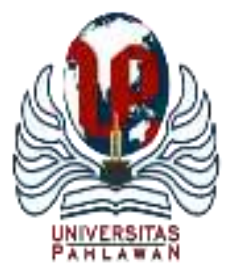

Edukatif : Jurnal Ilmu Pendidikan Volume 4 Nomor 1 Tahun 2022 Halm 778 - 785

EDUKATIF: JURNAL ILMU PENDIDIKAN

Research \& Learning in Education

https:/ledukatif.org/index.php/edukatif/index

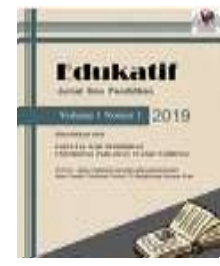

\title{
Analisis Framing Berita Korupsi Maskapai Garuda Indonesia pada Media Online Cnbcindonesia.com dan Sindonews.com sebagai Bahan Ajar Teks Berita di SMP
}

\author{
Achmad Khoiruddin ${ }^{1 凶}$, Hendra Setiawan ${ }^{2}$ \\ Universitas Singaperbangsa Karawang, Indonesia ${ }^{1,2}$ \\ E-mail : $\underline{1810631080079 @ \text { student.unsika.ac }^{1}}, \underline{\text { hendra.setiawan@ fkip.unsika.ac.id }}{ }^{2}$
}

\begin{abstract}
Abstrak
Pandemi Covid-19 tak gentar mempersurut isu korupsi di Indonesia. Hal tersebut karena adanya potensi para oknum melakukan tindak korupsi dalam berbagai sektor. Tujuan penelitian ini untuk melihat pembingkaian Cnbcindonesia.Com dan Sindonews.Com dalam memberitakan isu korupsi yang terjadi pada PT Garuda Indonesia. Metode penelitian menggunakan paradigma penelitian kualitatif serta analisis pembingkaian Zhong Dang Pan dan M. Kosicki. Penelitian ini diharapkan mampu memberikan pemahaman anti korupsi bagi generasi penerus bangsa. Hasil temuan memperlihatkan kedua media dalam membingkai berita secara sintaksis yaitu menekankan pada maksimalisasi peran pemerintah dalam membentuk opini positif kepada masyarakat. Kedua media sudah menggunakan unsur pembangun berita $(5 \mathrm{~W}+1 \mathrm{H})$ sehingga pemberitaan lebih mudah dipahami oleh pembaca. Struktur tematik Cnbcindonesia.Com menampilkan poin-poin sehingga lebih rinci dan baku. Sedangkan Sindonews.Com langsung memaparkan inti permasalahan sehingga lebih adaftif. Dalam pemberitaan Sindonews.Com menggunakan kata 'korupsi' untuk menegaskan penyebab terjadinya kebangkrutan pada PT Garuda Indonesia. Sedangkan Cnbcindonesia.Com menggunakan istilah lain untuk menyamarkan isu korupsi. Pemanfaatan hasil analisis disusun bahan ajar berupa modul pembelajaran dengan tujuan memudahkan guru dalam memberikan pengajaran teks berita di SMP kelas VIII yang fokus pada pengajaran anti korupsi.
\end{abstract}

Kata Kunci: analisis framing, bahan ajar, berita korupsi, maskapai garuda Indonesia, pengajaran anti korupsi

\begin{abstract}
The Covid-19 pandemic is not afraid to reduce the issue of corruption in Indonesia. This is because of the potential for individuals to commit acts of corruption in various sectors. The purpose of this study is to see the framing of Cnbcindonesia.Com and Sindonews.Com in reporting the issue of corruption that occurred at PT Garuda Indonesia. The research method uses a qualitative research paradigm and framing analysis of Zhong Dang Pan and M. Kosicki. This research is expected to be able to provide an understanding of anti-corruption for the next generation of the nation. The findings show both media in framing news syntactically, namely emphasizing on maximizing the government's role in forming positive opinions to the public. Both media have used news-building elements $(5 \mathrm{~W}+1 \mathrm{H})$ so that the news is easier to understand by readers. The thematic structure of Cnbcindonesia.Com displays points so that it is more detailed and standardized. Meanwhile, Sindonews.Com immediately explained the essence of the problem so that it was more adaptive. In the news, Sindonews.Com used the word 'corruption' to emphasize the cause of the bankruptcy of PT Garuda Indonesia. Meanwhile, Cnbcindonesia.Com uses other terms to disguise the issue of corruption. Utilizing the results of the analysis, teaching materials are arranged in the form of learning modules to make it easier for teachers to teach news texts in class VIII junior high schools that focus on teaching anti-corruption.
\end{abstract}

Keywords: analysis framing, teaching materials, corruption news, Garuda Indonesia airline, anti-corruption teaching

Copyright (c) 2022 Achmad Khoiruddin, Hendra Setiawan

$\triangle$ Corresponding author:

Email : 1810631080079@student.unsika.ac

DOI : https://doi.org/10.31004/edukatif.v4i1.2005

ISSN 2656-8063 (Media Cetak)

ISSN 2656-8071 (Media Online)

Edukatif : Jurnal Ilmu Pendidikan Vol 4 No 1 Tahun 2022 p-ISSN 2656-8063 e-ISSN 2656-8071 


\section{PENDAHULUAN}

Pandemi Covid-19 menjadi permasalahan yang tak bisa dielakan dalam kurun tiga tahun terakhir. Virus yang mula muncul di Wuhan Cina ini menjalar cepat hingga 190 negara di dunia dalam kurun waktu kurang dari satu tahun. Berbagai sektor terkena dampak dengan adanya pandemi Covid-19, seperti pendidikan, sosial, ekonomi, hingga permasalahan domestik (Nasution, DKK., 2020; Radhitya, DKK., 2020; Siahaan, 2020).

Indonesia sebagai satu dari ratusan negara yang terdampak pandemi Covid-19 mempunyai permasalahan signifikan dalam sektor ekonomi. Salah satunya permasalahan korupsi. Adanya pandemi Covid19 tak gentar mempersurut isu korupsi di Indonesia. Bahkan, isu tersebut semakin berkembang dengan subur saat pandemi Covid-19 berlangsung (Launa \& Lusianawati, 2021). Hal tersebut karena adanya potensi para oknum melakukan tindak korupsi dalam berbagai sektor.

Tercatat lebih lebih dari seratus kasus korupsi muncul dalam kurun lima tahun terakhir. Baik korupsi di tingkat daerah, regional, hingga nasional. Sehingga pemberitaan kasus korupsi santer dibicarakan di media masa baik lokal maupun nasional. Kasus korupsi secara tak langsung mampu memudarkan karakter bangsa sehingga jati diri anak bangsa semakin memudar (Dewi, DKK., 2021; Handoyo \& Susanti, 2014; Karim, DKK., 2021). Atas dasar tersebut diperlukan penguatan karakter guna mempersiapkan anak bangsa anti korupsi (Angraini, 2014; Sukarismanti \& Samsudin, 2021; Suryani, 2015). Sekolah sebagai lembaga pendidikan juga rentan terkena tindak korupsi. Hal tersebut sejalan dengan penelitian Yusfitriadi (2015) terdapat beberapa tindak korupsi yang terjadi di dunia pendidikan, seperti orang tua suap guru, pemotongan dana beasiswa, guru menaikan harga buku diluar batas normal, Pegawai Negeri Sipil (PNS) tetap mendapatkan gajih walau sering membolos, hingga berbagai tindak korupsi lainnya. Hal tersebut apabila dibiarkan mampu membentuk budaya korupsi pada peserta didik sehingga mempersurut karakter anak bangsa.

Maka dari itu diperlukan pemahaman anti korupsi untuk peserta didik guna meminimalisir tindak kejahatan korupsi pada generasi penerus bangsa. Media masa sebagai pers mampu memberikan informasi terkait permasalahan yang terjadi di masyarakat. Hal itu selaras dengan pernyataan Habibie (2018) bahwa media massa bertujuan memberikan konsumsi kepada publik terkait perkembangan negara hingga budaya. Media masa mempunyai ideologi tertentu dalam memberikan pemberitaan (Muttaqin, 1970). Hal tersebut disebabkan karena media selalu ditopang oleh pengelola media yang memberikan keputusan mengenai fokus hingga selingkung media. Sehingga setiap media mempunyai gaya berbeda dengan media lain.

Media online sebagai sarana komunikasi yang memanfaatkan koneksi internet mampu mempermudah dalam melakukan pengaksesan. Selain itu, media online menpunyai kemajuan yang masif baik dari segi penggunanya maupun medianya. Hal itu, selaras dengan penelitian Gunawan, DKK., (2021) bahwa pengguna internet di Indonesia terus betambah, bahkan $73,7 \%$ populasi masyarakat Indonesia memiliki akses internet setiap harinya di tahun 2021. Atas dasar tersebut peneliti bermaksud melakukan kajian terhadap media online. Adapun portal media online yang menjadi subjek penelitian yaitu Cnbcindonesia.Com dan Sindonews.Com.

Cnbcindonesia.Com merupakan situs berita CNBC Indonesia yang fokus membahas berbagai berita terkini, riset, dan analisis mendalam terkait ekonomi, bisnis, pasar modal, bank, investasi, dan ekonomi syariah. Media ini pertama kali diluncurkan pada 8 Februrai 2018. Setidaknya sejak tiga tahun berdinya Cnbcindonesia.Com telah memberikan warna dan kontribusi dalam pemberitaan di Indonesia.

Sindonews.Com merupakan situs berita yang berdiri sejak 4 Juli 2021 dibawah naungan manajemen PT. Sindonews Portal Indonesia (SPI). Fokus berita yang disiarkan oleh Sindonews.Com di antaranya nasional, ekonomi dan bisnis, sains, lifestyle, edukasi, dan beberapa kategori lainnya yang disusun secara komprehensif.

Framing berita merupakan sebauah cara yang digunakan oleh media dalam menonjolkan pesan dalam sebuat pemberitaan. Eriyanto (2018) mengatakan bahwa framing berkenaan dengan struktur pembangun berita mulai dari struktur hingga proses wartawan mengkontruksi pesan. Framing berfungsi menyusun peristiwa sehingga mampu dimaknai oleh masyarakat (Kurniawan \& Muktiyo, 2019). Analisis framing Zhong Dang 
Pan dan M. Kosicki digunakan karena paradigma tersebut mampu membongkar pembingkaian berita secara detail dan terstruktur. Pemilihan model ini selaras dengan pernyataan Hidayat (2021) bahwa analisis pembingkaian menggunakan framing Zhong Dang Pan dan M. Kosicki mampu melihat kontruksi wacana yang dibangun wartawan.

Pan dan Kosicki (dalam Cabucci, M. O., \& Maulina, 2021) mengatakan bahwa framing sebagai strategi teks berita mengenai ideologi atau cara pandangan wartawan dalam mengkontruksi sebuah peristiwa ke dalam sebuah berita dengan berbagai pertimbangan. Fokus analisis framing Zhong Dang Pan dan M. Kosicki (dalam Eriyanto, 2018) yaitu sintaksis (bagaimana wartawan mengkontruksi fakta dalam berita, seperti latar, lead, kutipan, dan sebagainya), skrip (bagaimana wartawan menuturkan fakta-fakta yang ada), tematik (bagaimana wartawan mengkontruksi fakta ke dalam berita), dan retoris (bagaimana wartawan menonjolkan pesan dalam berita).

Pemilihan Cnbcindonesia.Com dan Sindonews.Com sebagai subjek penelitian karena kedua media tersebut memiliki eksistensi di masyarakat. Selain itu, kedua media tersebut memiliki perbedaan dalam mengkontruksi berita dapat dilihat dari unsur sintakis, skrip, tematik, dan retoris. Perbedaan tersebut karena adanya perbedaan ideologi media yang memuat kedua berita.

Penelitian ini berguna untuk memberikan pemahaman perbedaan antara dua portal berita. Selain itu, membantu pembaca mehamai isi berita yang dimuat dalam kedua portal. Penggunaan framing berguna memberikan kemudahan peserta didik tingkat SMP dalam memahami materi teks berita. Materi mengenai teks berita termaktub dalam silabus dan kurikulum yang masuk ke dalam Kompetensi Inti dan Kompetensi Dasar 3.1 dan 4.1 mengenai pengertian dan unsur teks berita. Penelitian ini selaras dengan kajian framing yang membahas $(5 \mathrm{~W}+1 \mathrm{H})$, sehingga penelitian dapat dimanfaatkan sebagai bahan ajar teks berita berupa modul pembelajaran. Pemilihan modul sebagai bahan ajar diharapkan mampu mempermudah peserta didik dalam memahami materi yang diajarkan guru. Hal tersebut sejalan dengan penelitian Pratiwi, DKK., (2020) pembuatan modul pembelajaran mampu meningkatkan kualitas pembelajaran dan memberikan pemahaman komprehensif terkait materi pembelajaran.

Terdapat beberapa penelitian yang sejalan dengan penelitian yang dilakukan. Pertama, penelitian Leliana, DKK., (2021) berjudul "Analisis Framing Model Robert Entman tentang Pemberitaan Kasus Korupsi Bansos Juliari Batubara di Kompas.Com dan BBCIndonesia.Com". Hasil penelitiannya memperlihatkan Kompas.Com dan BBCIndonesia.Com memberikan ruang informasi dan klarifikasi bagi pemerintah dan lembaga KPK dalam melakukan penertiban dan penanggulangan masalah korupsi dana bansos Covid-19. Kedua, penelitian Kusumawati, (2019) berjudul "Kajian Framing Korupsi e-KTP Setya Novanto pada Media Online". Hasil temuanya bahwa pengemasan berita online mengkontruksi massa bahwa Setya Novanto sebagai tersangka tindak korupsi. Penelitian terakhir yaitu penelitian Sovianti (2019) berjudul "Analisis Framing: Pemberitaan Penangkapan Kasus Korupsi e-KTP Setya Novanto di Media Daring Detik.Com dan Kompas.Com". Hasil temuanya memperlihatkan terdapat pemberitaan yang berbeda antara Detik.Com dan Kompas.Com dalam memberikan pemberitaan kepada masyarakat.

Ketiga penelitian terdahulu memiliki perbedaan dengan penelitian yang dilakukan. Perbedan meliputi, subjek penelitian, teori yang digunakan. Sedangkan persamaan dengan ketiga penelitian terdahulu yaitu samasama fokus mengkaji berita korupsi pada media masaa. Penelitian ini bertujuan untuk melihat pembingkaian yang dilakukan Cnbcindonesia.com dan Sindonews.com dalam melakukan pemberitaan kasus korupsi maskapai Garuda Indonesia. Hasil penelitian akan dimanfaatkan sebagai bahan Ajar pembelajaran bahasa Indonesia pada materik Teks Berita SMP kelas VIII dengan tujuan memudakan dan memberikan pemahaman pengajaran anti korupsi bagi generasi penerus bangsa. 
781 Analisis Framing Berita Korupsi Maskapai Garuda Indonesia pada Media Online Cnbcindonesia.com dan Sindonews.com sebagai Bahan Ajar Teks Berita di SMP - Achmad Khoiruddin, Hendra Setiawan DOI: https://doi.org/10.31004/edukatif.v4i1.2005

\section{METODE PENELITIAN}

Metode penelitian yang digunakan dalam penelitian ini adalah metode deskriptif kualitatif. Metode kualitatif merupakan metode yang fokus pada interpretasi teks. Hal tersebut sejalan dengan gagasan Steven Dukeshire dan Jennifer Thurlow (dalam Sugiyono, 2017: 3) bahwa penelitian kualitatif lebih menekankan pada data berupa kata-kata. Penggunaan metode kualitatif diharapkan mampu memperoleh hasil temuan secara mendalam mengenai topik yang angkat (Karim, A. A., \& Hartati, 2021). Cara pengambilan data dalam penelitian ini yaitu peneliti mencari berita-berita serupa dari dua media online. Tujuanya untuk membandingkan pembingkaian berita dalam kedua media online yang dikaji. Selain itu, peneliti mengumpulkan data-data pendukung berupa buku-buku dan jurnal-jurnal yang mendukung fokus penelitian. $।$

Tabel 1

Data Berita Sindonews.Com yang akan diteliti

\begin{tabular}{ccc}
\hline No. & \multicolumn{1}{c}{ Waktu Terbit } & \multicolumn{1}{c}{ Judul } \\
\hline 1. & Kamis, 11 November 2021 & Tak mampu bayar hutang, PT Garuda Indonesia Bangkrut \\
2. & Rabu, 24 November 2021 & Erick Thohir Bongkar Masalah Garuda dan Jiwasraya \\
\hline
\end{tabular}

Tabel 2

Data Berita Cnbcindonesia.Com yang akan diteliti

\begin{tabular}{ccc}
\hline No. & Waktu Terbit & \multicolumn{1}{c}{ Judul } \\
\hline 1. & Jumat, 12 November 2021 & Ini ‘Biang Kerok’ yang Bikin Utang Garuda Terus Menggunung! \\
2. & Rabu, 24 November 2021 & Lolos dari PKPU, Garuda Digugat Lagi ke Pengadilan \\
\hline
\end{tabular}

\section{HASIL DAN PEMBAHASAN PENELITIAN}

Berikut ini hasil dan pembahasan analisis framing berita korupsi Maskapai Garuda Indonesia pada media online Cnbcindonesia.Com dan Sindonews.Com dan pemanfaatnya sebagai Bahan Ajar Teks Berita di SMP.

\section{Analisis Berita Korupsi Maskapai Garuda pada Sindonews.com}

\section{Tabel 3}

\section{Hasil analisis Berita Sindonews. Com}

\begin{tabular}{|c|c|c|c|c|c|}
\hline No. & Sintaksis & Skrip & Tematik & Retoris & Judul \\
\hline 1. & $\begin{array}{l}\text { Penggunaan lead berita } \\
\text { memaparkan pernyataan } \\
\text { kementerian BUMN yang } \\
\text { menyatakan bahwa PT } \\
\text { Garuda Indonesia } \\
\text { Bangkrut. Dalam penulisan } \\
\text { berita disampaikan } \\
\text { penyebab terjadinya } \\
\text { kebangkrutan pada PT } \\
\text { Garuda Indonesia yaitu } \\
\text { nilai ekuitas yang terus } \\
\text { mengalami pembengkakan. } \\
\text { Sumber tersebut berasal } \\
\text { dari wakil menteri BUMN } \\
\text { Kartika Wirjoatmodjo saat } \\
\text { rapat kerja dengan komisi } \\
\text { VI DPR RI. }\end{array}$ & $\begin{array}{l}\text { Penggunaan } \\
\text { skrip mampu } \\
\text { memberikan } \\
\text { data dan } \\
\text { informasi, } \\
\text { sehingga } \\
\text { berita ini } \\
\text { sudah sesuai } \\
\text { dengan 5W+ } \\
\text { 1H dan layak } \\
\text { dikonsumsi } \\
\text { masyarakat. }\end{array}$ & $\begin{array}{l}\text { Berita ini ditulis } \\
\text { berdasarkan pernyataan } \\
\text { yang dikemukakan oleh } \\
\text { kementerian BUMN. } \\
\text { Kemudian dikuatkan oleh } \\
\text { wartawan dan reporter } \\
\text { dengan menyajian data } \\
\text { melaui video. }\end{array}$ & $\begin{array}{l}\text { Struktur retoris } \\
\text { fokus membahas } \\
\text { penyebab PT. } \\
\text { Garuda Indonesia } \\
\text { mengalami } \\
\text { kebangkrutan. }\end{array}$ & $\begin{array}{l}\text { Tak } \\
\text { mampu } \\
\text { bayar } \\
\text { hutang, PT } \\
\text { Garuda } \\
\text { Indonesia } \\
\text { Bangkrut }\end{array}$ \\
\hline 2. & $\begin{array}{l}\text { Penggunaan lead berisi } \\
\text { peranyataan menteri } \\
\text { BUMN Erick Thohir }\end{array}$ & $\begin{array}{l}\text { Penggunaan } \\
\text { skrip mampu } \\
\text { memberikan }\end{array}$ & $\begin{array}{l}\text { Berita ini ditulis } \\
\text { berdasarkan pernyataan } \\
\text { yang dikemukakan oleh }\end{array}$ & $\begin{array}{l}\text { Terdapat } \\
\text { pengunaan karta } \\
\text { "korupsi" dalam }\end{array}$ & $\begin{array}{l}\text { Erick } \\
\text { Thohir } \\
\text { Bongkar }\end{array}$ \\
\hline
\end{tabular}


782 Analisis Framing Berita Korupsi Maskapai Garuda Indonesia pada Media Online Cnbcindonesia.com dan Sindonews.com sebagai Bahan Ajar Teks Berita di SMP - Achmad Khoiruddin, Hendra Setiawan DOI: https://doi.org/10.31004/edukatif.v4i1.2005

$\begin{array}{lllll}\text { mengenai permasalahan } & \text { data dan } & \text { kementerian BUMN yaitu } & \text { lead mampu } & \text { Masalah } \\ \text { yang dihadapi oleh PT } & \text { informasi, } & \text { Erick Thohir dengan } & \text { memberikan } & \text { Garuda } \\ \text { Garuda Indonesia (Persero) } & \text { sehingga } & \text { penggunaan bahasa yang } & \text { pemahaman } & \text { dan } \\ \text { TBK dan PT Asuransi } & \text { skrip sudah } & \text { lugas, dan jelas sehingga } & \text { kepada pembaca } & \text { Jiwasraya } \\ \text { Jiwasraya BUMN. Erick } & \text { sesuai dengan } & \text { mudah untuk dipahami } & \text { mengenai isi } & \\ \text { Thohir menyatakan bahwa } & \text { 5W+ 1H dan } & \text { oleh pembaca. Terdapat } & \text { berita. Erick } & \\ \text { kedua PT tersebut } & \text { layak untuk } & \text { delapan paragraf yang } & \text { Thohir juga } & \\ \text { teridikasi tindak pidana } & \text { dikonsumsi } & \text { ditulis dengan runut dan } & \text { membahas } \\ \text { korupsi. } & \text { masyarakat. } & \text { saling berkesinambungan } & \text { penyebab PT. } & \\ & & \text { setiap paragrafnya saling } & \text { Garuda Indonesia } & \\ & & \text { koheren satu sama lain. } & \begin{array}{l}\text { yang mengalami } \\ \text { kebangkrutan. }\end{array} & \\ & & & & \end{array}$

Analisis Berita Korupsi Maskapai Garuda pada CnbcIndonesia.Com

Tabel 4

Hasil analisis Berita Cnbcindonesia.Com

\begin{tabular}{|c|c|c|c|c|c|}
\hline No. & Sintaksis & Skrip & Tematik & Retoris & Judul \\
\hline 1. & $\begin{array}{l}\text { Pengguanaan lead } \\
\text { dalam berita ini } \\
\text { menunjukkan } \\
\text { pernyataan wakil } \\
\text { Menteri BUMN } \\
\text { Kartika Wirjoatmogjo } \\
\text { memaparkan kondisi } \\
\text { terkini PT Haruda } \\
\text { Indonesia. Serta } \\
\text { penyebab utang- } \\
\text { piutang yang } \\
\text { menyebabkan PT } \\
\text { Garuda Indonesia } \\
\text { mengalami } \\
\text { kebangkrutan. }\end{array}$ & $\begin{array}{l}\text { Penggunaan } \\
\text { skrip mampu } \\
\text { memberikan } \\
\text { data dan } \\
\text { informasi, } \\
\text { sehingga skrip } \\
\text { sudah sesuai } \\
\text { dengan 5W+ } \\
\text { 1H dan layak } \\
\text { untuk } \\
\text { dikonsumsi } \\
\text { masyarakat. }\end{array}$ & $\begin{array}{l}\text { Berita dipaparlam } \\
\text { secara rinci bahkan } \\
\text { terdapat poin-poin } \\
\text { yang menyebabkan } \\
\text { PT Garuda } \\
\text { Indonesia } \\
\text { mengalami } \\
\text { kebangkrutan. } \\
\text { Selain itu, didukung } \\
\text { dengan pernyataan- } \\
\text { pernyataan wakil } \\
\text { menteri BUMN } \\
\text { yaitu Kartika } \\
\text { Wirjoatmodjo yang } \\
\text { ditampilkan secara } \\
\text { rinci dan jelas. }\end{array}$ & $\begin{array}{l}\text { Terdapat penggunaan } \\
\text { kata 'Biang Kerok' } \\
\text { sebagai pengganti oknum } \\
\text { yang menjadi penyebab } \\
\text { utang-piutang PT. } \\
\text { Garuda Indonesia } \\
\text { semakin menumpuk. }\end{array}$ & $\begin{array}{l}\text { Ini 'Biang } \\
\text { Kerok’ } \\
\text { yang Bikin } \\
\text { Utang } \\
\text { Garuda } \\
\text { Terus } \\
\text { Menggunu } \\
\text { ng! }\end{array}$ \\
\hline 2. & $\begin{array}{l}\text { Penggunaan lead } \\
\text { dalam berita } \\
\text { memaparkan gugatan } \\
\text { yang ditujukan PT } \\
\text { Garuda Indonesia atas } \\
\text { perbuatan melawan } \\
\text { hukum. Gugatan } \\
\text { tersebut diajukan oleh } \\
\text { PT Prima Raya } \\
\text { Solusindo. }\end{array}$ & $\begin{array}{l}\text { Penggunaan } \\
\text { skrip mampu } \\
\text { memberikan } \\
\text { data dan } \\
\text { informasi, } \\
\text { sehingga skrip } \\
\text { sudah sesuai } \\
\text { dengan 5W+ } \\
1 \text { H dan layak } \\
\text { untuk } \\
\text { dikonsumsi } \\
\text { masyarakat. }\end{array}$ & $\begin{array}{l}\text { Berita ini ditulis } \\
\text { berdasarkan fakta } \\
\text { yang sebernarnya } \\
\text { terjadi. Selain itu, } \\
\text { didukung dengan } \\
\text { penggunaan bahasa } \\
\text { yang luwes dan } \\
\text { paragraf pendek } \\
\text { sehingga mudah } \\
\text { untuk dipahami oleh } \\
\text { pembaca. }\end{array}$ & $\begin{array}{l}\text { Berita ini ditulis } \\
\text { berdasarkan fakta yang } \\
\text { sebernarnya terjadi. } \\
\text { Selain itu, didukung } \\
\text { dengan penggunaan } \\
\text { bahasa yang luwes dan } \\
\text { paragraf pendek sehingga } \\
\text { mudah untuk dipahami } \\
\text { oleh pembaca. }\end{array}$ & $\begin{array}{l}\text { Lolos dari } \\
\text { PKPU, } \\
\text { Garuda } \\
\text { Digugat } \\
\text { Lagi ke } \\
\text { Pengadilan }\end{array}$ \\
\hline
\end{tabular}

\section{Pemanfaatan dalam Pengajaran Bahasa Indonesia}

Hasil penelitian memperlihatkan adanya persamaan temuan dengan penelitian terdahulu. Persamaan tersebut terlihat bahwa media mempunyai ideologi dalam mengkontruksi setiap berita. Atas dasar tersebut menyebabkan adanya perbedaan setiap media dalam membingkai suatu isu. Perbedaan penelitian ini dengan penelitian terdahulu yaitu hasil penelitian dimanfaatkan sebagai bahan ajar teks berita untuk tingkat SMP kelas VIII. Bahan ajar disusun berdasarkan perangkat pembelajaran mulai dati RPP, silabus, dan kurikulum yang telah ditetapkan kemdikbud. Bahan ajar berupa modul pembelajaran yakni berisi materi framing 
783 Analisis Framing Berita Korupsi Maskapai Garuda Indonesia pada Media Online Cnbcindonesia.com dan Sindonews.com sebagai Bahan Ajar Teks Berita di SMP - Achmad Khoiruddin, Hendra Setiawan DOI: https://doi.org/10.31004/edukatif.v4i1.2005

berdasarkan hasil analisis berita korupsi Maskapai Garuda Indonesia pada media Online Cnbcindonesia.Com dan Sindonews.Com dengan menggunakan paradigma framing Zhong Dang Pan dan M. Kosicki.

\section{KESIMPULAN}

Berdasarkan analisis yang dilakukan pada kedua media online dapat disimpulkan bahwa Sindonews.Com dalam penyampaian berita lebih banyak menampilkan sosok menteri BUMN yaitu Erick Thohir dengan menggunakan skema pemberitaan piramida terbalik dan fokus pada satu narasumber. Sedangkan Cnbindonesia.Com menghadirkan beberapa narasumber dan memanfaatkan konsep piramida terbalik. Struktur sintaksis kedua media lebih menekankan pada maksimalisasi peran pemerintah yang dapat membentuk opini positif. Kedua berita tersebut sudah menggunakan unsur pembangun berita $(5 \mathrm{~W}+1 \mathrm{H})$ sehingga pemberitaan lebih mudah dipahami oleh pembaca. Struktur tematik CnbcIndonesia.Com menampilkan poin-poin sehingga lebih rinci dan baku. Sedangakan Sindonews.Com langsung memaparkan inti permasalahan sehingga lebih luwes. Dalam pemberitaan Sindonews.Com menggunakan kata 'korupsi' untuk menegaskan penyebab terjadinya kebangkrutan pada PT Garuda Indonesia. Sedangkan Cnbcindonesia.Com menggunakan istilah lain untuk menyamarkan istilah korupsi. Pemanfaatan hasil analisis disusun bahan ajar berupa modul pembelajaran dengan tujuan memudahkan guru dalam memberikan pengajaran teks berita di SMP kelas VIII. Serta memberikan pemahaman pengajaran anti korupsi bagi generasi penerus bangsa.

\section{UCAPAN TERIMA KASIH}

Peneliti mengucapkan terima kasih kepada bapak Hendra Setiawan selaku pembimbing serta saudara Ahmad Abdul Karim yang senantiasa menjadi partner diskusi dalam penyusunan penelitian ini.

\section{DAFTAR PUSTAKA}

Angraini, H. (2014). Penguatan Karakter Bangsa Sebagai Langkah Awal Menumbuhkan Jiwa Anti Korupsi. Pemberantasan Korupsi di Indonesia, 177.

Anwardi, riky. 2021. Tak Mampu Bayar Hutang, PT Garuda Indonesia Bangkrut[online].

Tersedia:https://video.sindonews.com/play/37515/tak-mampu-bayar-hutang-pt-garuda-indonesiabangkrut

Cabucci, M. O., \& Maulina, P. (2021). Analisis Framing Pemberitaan Kebakaran Hutan dan Lahan PT. Agro Sinergi Nusantara Pada Media Online Lokal dan Nasional. Jurnal Komunikasi Dan Kajian Media, 5(2), $205-216$.

Dewi, D. A., Furmasari, Y. F., Septianingrum, A. D., \& Yunianti, V. D. (2021). Penerapan Pendidikan Kewarganegaraan sebagai Penguat Sikap Bela Negara Bagi Siswa Sekolah Dasar. Edukatif: Jurnal Ilmu Pendidikan, 3(6), 4683-4688.

Eriyanto. (2018). Analisis Framing, Kontruksi, Ideologi, dan Politik Media. LKIS GROUP.

Gunawan, R., Aulia, S., Supeno, H., Wijanarko, A., Uwiringiyimana, J. P., \& Mahayana, D. (2021). Adiksi Media Sosial dan Gadget bagi Pengguna Internet di Indonesia. Techno-Socio Ekonomika, 14(1), 1. https://doi.org/10.32897/techno.2021.14.1.544

Habibie, D. K. (2018). Dwi Fungsi Media Massa. Interaksi: Jurnal Ilmu Komunikasi, 7(2), 79. https://doi.org/10.14710/interaksi.7.2.79-86

Handoyo, E., \& Susanti, M. H. (2014). Dampak Korupsi Melalui Pendidikan Anti Korupsi Dalam Membentuk Generasi Muda Yang Jujur Dan Berintegritas di SMA Semesta Kota Semarang. Jurnal Abdimas, 18(1).

Hidayat, M. (2021). Analisis Framing Pemberitaan Daerah Istimewa Minangkabau di Media Online Tempo. co. KOMUNIKA: Jurnal Dakwah Dan Komunikasi, 17(2), 15-29. 
784 Analisis Framing Berita Korupsi Maskapai Garuda Indonesia pada Media Online Cnbcindonesia.com dan Sindonews.com sebagai Bahan Ajar Teks Berita di SMP - Achmad Khoiruddin, Hendra Setiawan DOI: https://doi.org/10.31004/edukatif.v4i1.2005

Karim, A. A., \& Hartati, D. (2021). Nilai-Nilai Humanisme dalam Puisi Bertema Palestina Karya Helvy Tiana Rosa. Jurnal Sastra Indonesia, 10(2), 93-101. https://doi.org/10.15294/jsi.v10i2.43918

Karim, A. A., Firdaus, M. Y., Dewi, R. K., Yuliani, Y., \& Hartati, D. (2021). Pemanfaatan Metode Impresif Terhadap Proses Pengembangan Karakter Siswa. SeBaSa, 4(2), 152-166.

Kurniawan, D., \& Muktiyo, W. (2019). Framing Berita Presiden Donald Trump oleh Media Asing dan Media Nasional. Jurnal Intelektiva, 01(03), 17-23.

Kusumawati, H. S., Rahayu, N. T., \& Handayani, R. (2019). Analisis Framing Berita Korupsi e-KTP Setya Novanto Pada Media Online. In Annual Conference of Communication, Media and Culture (ACCOMAC), 2(1), 52-59.

Launa, \& Lusianawati, H. (2021). Potensi korupsi dana bansos di masa pandemi covid-19. Majalah Semi Ilmiah Populer Komunikasi Massa, 2 (1), 7. 2721-6306

Leliana, I., Herry, H., Suratriadi, P., \& Enrieco, E. (2021). Analisis Framing Model Robert Entman tentang Pemberitaan Kasus Korupsi Bansos Juliari Batubara di Kompas.com dan BBCIndonesia.com. Cakrawala - Jurnal Humaniora, 21(1), 60-67. https://doi.org/10.31294/jc.v21i1.10042

Moleong, L. J. (2017). Metodologi Penelitian Kualitatif. PT. Remaja Rosdakarya.

Muttaqin, A. (1970). Ideologi Dan Keberpihakkan Media Massa. Komunika: Jurnal Dakwah Dan Komunikasi, 5(2), 185-198. https://doi.org/10.24090/komunika.v5i2.168

Nasution, D. A. D., Erlina, E., \& Muda, I. (2020). Dampak Pandemi COVID-19 terhadap Perekonomian Indonesia. Jurnal Benefita, 5(2), 212-224. https://doi.org/10.22216/jbe.v5i2.5313

Pratiwi, T. M., \& Mulyati, Y. (2020). Penerapan Modul Berbasis Android dalam Pembelajaran Menulis Cerpen. . . In Seminar Internasional Riksa Bahasa, 502-506.

Radhitya, T. V., Nurwati, N., \& Irfan, M. (2020). Dampak Pandemi Covid-19 Terhadap Kekerasan dalam Rumah Tangga. Jurnal Kolaborasi Resolusi Konflik, 2(2), 111-119. https://doi.org/10.24198/jkrk.v2i2.29119

Siahaan, M. (2020). Dampak pandemi Covid-19 terhadap dunia pendidikan. Dampak Pandemi Covid-19 Terhadap Dunia Pendidikan, 2O(2).

Suparjo, Ramalan. 2021. Erick Thohir Bongkar Persamaan Masalah Garuda dan Jiwasraya[online]. Tersedia:https://ekbis.sindonews.com/read/608761/34/erick-thohir-bongkar-persamaan-masalah-garudadan-jiwasraya-1637741470

Sovianti, R., Bhayangkara, U., \& Raya, J. (2019). Analisis Framing: Pemberitaan Penangkapan Kasus Korupsi E-KTP Setya Novanto di Media Daring Detik.Com dan Kompas.Com. Jurnal Komunikasi, Masyarakat Dan Keamanan, 1(1), 47-61. http://jurnal.ubharajaya.ac.id/index.php/komaskam/article/view/450

Sugiyono. (2017). . Metode Penelitian Kualitatif. Penerbit Alfabeta.

Sukarismanti, \& Samsudin. (2021). Edukatif : Jurnal Ilmu Pendidikan Integrasi Kearifan Lokal dalam Bahan Ajar Antropolinguistik sebagai Upaya Penguatan Pemahaman dan Karakter Mahasiswa. Edukatif: Jurnal Ilmu Pendidikan, 3(5), 3339-3349.

Suryani, I. (2015). Penanaman Nilai-Nilai Anti Korupsi di Lembaga Pendidikan Perguruan Tinggi Sebagai Upaya Preventif Pencegahan Korupsi Ita. Jurnal Visi Komunikasi, 14(02), 285-301. http://publikasi.mercubuana.ac.id/files/journals/16/articles/425/submission/copyedit/425-1086-1-CE.pdf

Wareza, Monica. 2021. Lolos dari PKPU, Garuda Digugat Lagi ke Pengadilan[online]. Tersedia: https://www.cnbcindonesia.com/market/20211124100511-17-293949/lolos-dari-pkpu-garuda-digugatlagi-ke-pengadilan

Wareza, Monica. 2021. Ini 'Biang Kerok' yang Bikin Utang Garuda Terus Menggunung![online]. Tersedia:https://www.cnbcindonesia.com/market/20211111184125-17-290879/ini-biang-kerok-yangbikin-utang-garuda-terus-menggunung 
785 Analisis Framing Berita Korupsi Maskapai Garuda Indonesia pada Media Online Cnbcindonesia.com dan Sindonews.com sebagai Bahan Ajar Teks Berita di SMP - Achmad Khoiruddin, Hendra Setiawan DOI: https://doi.org/10.31004/edukatif.v4i1.2005

Yusfitriadi, Y. (2015). Perilaku Korupsi Di Sekolah. Jurnal Lingua, 1(106), 90-100. 